Anna Lewandowska, Gerd Antos

In cooperation with Dana Gläßer

7 Cognitive Apects of Proverbs ${ }^{81}$

\title{
7.1 Introduction
}

From the cognitive point of view proverbs are linguistically and culturally coined frames. Especially in spoken language, these frames work well for knowledge transfer due to their conciseness. Usually, proverbs are linguistically easy to identify based on their stereotyped character and consistence. Their economised form helps the speaker to remember and recognise them easily. Therefore, proverbs can be referred to as verbal stereotypes of knowledge which allow their users to comment on, standardise and evaluate new situations with the help of known social clichés. Against this background, we pose the following questions: What makes proverbs stereotyped? Which influence has the linguistic form of proverbs on our ability to memorize and duplicate them? Which role do proverbs play for social knowledge transfer? Henceforth, we will discuss the above questions under a cognitive point of view. We will concentrate on Lakoff and Johnson's Conceptual Metaphor Theory as frame to create a cognitivist understanding of proverbs (Lakoff \& Johnson, 1992).

\subsection{Lakoff and Johnson's Conceptual Metaphor Theory}

The Conceptual Metaphor Theory by George Lakoff and philosopher Mark Johnson is based on the assumption that "metaphor is pervasive in everyday life, not just in language but in thought and action. Our ordinary conceptual system, in terms of which we both think and act, is fundamentally metaphorical in nature” (Lakoff \& Johnson, 1992: 3).

81 We would like to thank Dana Gläßer for her conscientious translation and Wolfgang Mieder (Burlington, Vermont) for his critical review and suggestions. 
Around 1980, this thesis ${ }^{82}$ was revolutionary. It is premised on a then new cognitivist approach which has been defined more precisely through the central term metaphorical concept (MC):

The concepts that govern our thought are not just matters of the intellect. They also govern our everyday functioning, down to the most mundane details. Our concepts structure what we perceive, how we get around in the world, and how we relate to other people. Our conceptual system thus plays a central role in defining our everyday realities. If we are right in suggesting that our conceptual system is largely metaphorical, then the way we think, what we experience, and what we do every day is very much a matter of metaphor (Lakoff \& Johnson, 1992: 3).

The new idea behind Lakoff and Johnson's theory is that metaphors are no longer seen as purely linguistic phenomena, but from the cognitivist point of view as a basic rational instrument of orientation and world interpretation:

In cognitive linguistics, the metaphor leaves its past as a mere embellishment once and for all behind. She is no longer a stylistic device to illustrate a circumstance visually, but she is part of the knowledge of this circumstance as well as a part of its perspectival evaluation. Simultaneously, in terms of language she is irreplaceable in the communication of new thoughts or new semantic contents. She serves as a link between the known and the unknown, the specific and the abstract. And she serves as a link between language and cognition (Drewer, 2003: 10). ${ }^{83}$

The question remains of why metaphors work so well for both the creation of frames and the transfer of knowledge. According to Lakoff and Johnson the main function of a metaphor entails making abstract and complex contexts linguistically and cognitively more comprehensible using well-known images. Therefore, metaphors systematically close the loop between a cognitively elusive field of experience, the so-called target domain of the metaphor, with a more comprehensible second field of experience, the source domain of the metaphor, by projecting a part of the source

82 Lakoff and Johnson's Conceptual Metaphor Theory is revolutionary and non-revolutionary at the same time, Liebert (1992: 12ff): On the one hand, the idea that metaphors are primarily no longer seen as linguistical-rhetorical patterns, but rather as cognitive concepts, has affected the present discussion fundamentally. On the other hand, the influence of the American theory of cognition has been blinded out (see the bibliography of Metaphors We Live By which contains merely 20 entries, out of which three are by Lakoff himself!) as well as its widely ignored European precursors.

83 Ger. original: "In der Kognitiven Linguistik lässt die Metapher ihre Vergangenheit als bloßes Schmuckstück endgültig hinter sich. Sie ist nicht länger ein Stilmittel, um einen Sachverhalt bildhaft zu veranschaulichen, sondern sie ist Teil des Wissens über diesen Sachverhalt sowie Teil seiner perspektivischen Bewertung. Gleichzeitig ist sie auf sprachlicher Ebene bei der Kommunikation neuer Gedanken bzw. neuer semantischer Gehalte unersetzlich. Sie schlägt eine Brücke zwischen dem Bekannten und dem Unbekannten, dem Konkreten und dem Abstrakten. Und sie schlägt eine Brücke zwischen Sprache und Kognition.” 
knowledge onto the target domain ${ }^{84}$. Please remark that instead of isolated components entire bodies of knowledge/ frames are created. Hence, we call the feature of cognitively creating abstract knowledge on the basis of specific images projection.

\subsection{Metaphorical Concepts}

In this section we would like to explain the central term of the proverb and metaphorical concept (MC) TIME IS MONEY using the trope about time and money as an example. This concept is unique in each time and culture, but has developed in our modern Western industrial society in the first place. Not only does it reflect an apparently quite natural everyday experience in dealing with time and money in market-based societies, but it also pre-structures our speech about this (new) experience in multiple variations. The following chart illustrates this correlation with (a slightly modified version of) Lakoff and Johnson's examples (1992):

Metaphorical Concept Time Is Money

You're wasting my time.

This gadget will save you hours.

I don't have the time to give you.

How do you spend your time these days?

I've invested a lot of time in her.

I don't have enough time to spare for that.

You're running out of time.

You need to budget your time.

Is that worth your while?

Do you have much time left?

He's living on borrowed time.

You don't use your time profitably.

I lost a lot of time when I got sick.

Thank you for your time.

The relationships between the expressions listed above, the metaphorical concept and the typical everyday activities within a society can be distinguished regarding the following three levels:

84 See the following example Time is Money: money is the easily comprehensible source domain whereas time is the elusive target domain of this metaphor. 
Language: In phrasing the metaphorical concept we orientate ourselves initially by the language use: Some expressions “...refer specifically to money (spend, invest, budget, profitably, $[. .$.$] ), others to limited resources (use, [...], have enough of, run out$ of), and still others to valuable commodities (have, give, lose, thank you for)" (Lakoff \& Johnson, 1992: 9).

Cognition: „The metaphorical concepts TIME IS MONEY, TIME IS A RESOURCE, and TIME IS A VALUABLE COMMODITy form a single system based on subcategorization, since in our society money is a limited resource and limited resources are valuable commodities. These subcategorization relationships characterize entailment relationships between metaphors. TIME IS MONEY entails that TIME IS A LIMITED RESOURCE, which entails that TIME IS A VALUABLE COMMODITY” (Lakoff \& Johnson, 1992: 9).

Actions: Not only do we talk in an exemplified way nor do we have only one respective metaphorical concept, but we act that way, too: “telephone message units, hourly wages, hotel room rates, yearly budgets, interest on loans, and paying your debt to society by 'serving time'. These practices [...] have arisen in modern industrialized societies and structure our basic everyday activities in a very profound way" (Lakoff \& Johnson, 1992: 8).

According to Lakoff and Johnson the accomplishment of the metaphor entails the ability to operate on all three levels (and not only on the language level). Further on, metaphors can become more intense in a reciprocally feed-backed way ${ }^{85}$.

\subsection{Epistemological Essentials}

The Conceptual Metaphor Theory by Lakoff and Johnson ${ }^{86}$ is based on an epistemology which contradicts the objectivistic understanding of thinking and meaning:

Thought is [...] not understood as a reflection of reality. In fact, the aspect of being able to deal with the world as a human has priority, the optimal human function in his environment. Both

85 With this model it is possible to explain the opposite, i.e. the decrease of the graphic quality: some metaphors fade because their corresponding actions no longer exist, e.g. in German Ich fühle mich wie gerädert. [ee: I feel absolutely whacked.].The German expression goes back to one of the most horrible kinds of execution: in the past, a criminal was sentenced to have his bones or limbs broken by a wheel in order to weave him onto the wheel' - Röhrich, Lutz (1994). Lexikon der sprichwörtlichen Redensarten (Band 4). Also see the items: sich wie gerädert fühlen which means to feel exhausted through big efforts as well as wie zerschlagen fühlen [to feel knocked up] (Röhrich, Lutz,1994: 1220).

86 Mark Johnson's The body in the mind (1987) deserves a particular mention here; Liebert (1992) and Baldauf (1997: 60). 
the human nature and his style of interaction with the world coin his thoughts, which will now come across as embodied (Baldauf, 1997: 65). ${ }^{87}$

Johnson claims that the human body and what we experience with it is the starting point of every theory of meaning. It is supposed to show "how physical experiences, perceptions and well-rehearsed physical procedures [...] [coin] the meaning of language and things" (Liebert, 1992: 35). To put it simply, higher thinking is based on a pre-linguistically or pre-conceptually experiencable embodiment in the end. Thus, Johnson as well as Lakoff represents the "primacy of the structure of the pre-conceptual embodied experience” (Liebert, 1992: 36). Lakoff and Johnson's approach emanates from the priority of the cognitive opposite to language. Therefore, the creation of meaning goes one-way from the pre-linguistic experience, from images and corporeality towards their manifestation in language:

[If] basic ideas emerge directly from non-conceptual, graphic or basic level structures, they are determinated by both these pre-conceptual structures just like the so deriving ideas. There is no way back from language or ideas to experienceable structures (Liebert, 1992: 79). ${ }^{88}$

We will comment on this idea again subsequently.

\subsection{Proverb Concepts (PCs)}

Especially in the nineteenth and the beginning of the twentieth centuries, proverbs were used to express the cultural identity of a particular society (or nation, time,

87 Ger. original: "Denken wird (...) nicht als eine Spiegelung der Realität verstanden. Im Vordergrund steht vielmehr der Aspekt des Zu Rechtfindens des Menschen in der Welt, die bestmögliche Funktion des Menschen in seinem Umfeld. Sowohl die Beschaffenheit des Menschen als auch die Art seiner Interaktion mit der Welt prägen das Denken, welches folglich als körpergebunden (embodied) verstanden wird.“

88 Ger. original: “(... W)enn die Grundbegriffe direkt aus nichtbegrifflichen, bildschematischen und Basisebenen-Strukturen emergieren, sind sie und damit abgeleiteten Begriffe von diesen beiden vorbegrifflichen Strukturen determiniert. Es gibt keinen Weg von der Sprache oder den Begriffen zu Erfahrungsstrukturen zurück." 
profession etc.). Like in fairytales and folk songs, proverbs reflected the soul of a nation ${ }^{89}$.

From the cognitivist point of view, proverbs can be perceived as stereotyped speech-forms that, like metaphors, are based on socially efficient cognitive concepts!

The underlying hypothesis is that many proverbs and metaphors share a similar or even identical cognitive structure. Evidence for this link between metaphors and proverbs can be found in their equivalent imagery ${ }^{90}$. Aristotle's Rhetoric already states that proverbs “...are explicitly referred to as metaphors; even if it is not explicitly said that metaphoricity is an obligatory feature of proverbs, or only optional (though common)" (Grzybek, 1998: 133). ${ }^{91}$

The cognitive influence of proverbs as well as metaphors rests upon the pre-linguistic and pre-conceptual imagery although there is a difference between figurative (or metaphorical) and non-figurative proverbs ${ }^{92}$. Especially in so-called motivated ${ }^{93}$ proverbs this correlation is conveyed, such as No rose without a thorn. The message of this rose-metaphor is easily understood: Even the most beautiful things have (minor) disadvantages. ${ }^{94}$

In the extension of Lakoff and Johnson's approach, we will now take the manifold parallels between the cognitivist interpretation of metaphors and proverbs into account in order to define metaphors and the comprehension of proverbs. Let us look at the following analogies:

Imagery: Many paremiologists regard the imagery as the central characteristic of proverbs.

89 Röhrich \& Mieder (1977: 70). In the polemic about Die Deutschen und Franzosen nach dem Geist ihrer Sprachen und Spüchwörter [The Germans and the French in the spirit of their languages and proverbs] by J. Venedey (1842) it says: "In language and proverb does the German substance live...”. According to Venedey, we can draw conclusions on the values rooted in a society from the firmly established sentences of a language. German expressions like Freundes Stimme ist Gottes Stimme [The voice of a friend is God's voice] or Gleichgesinnt macht gute Freunde [Like-minded makes good friends] point to the fact that friendship is something higher for the German and displays his non-material need whereas in French a material interest clearly dominates” (Lüger, 1999: 60).

90 Permjakov considers the pictorially motivated overall meaning as a necessary criterion for actual proverbs, see also Grzybek (1984) or Lüger (1999: 68ff.) for general phraseology.

91 Ger. original: “(...) explizit als Beispiele von Metaphern bezeichnet; wenn auch nicht explizit gesagt wird, ob Metaphorizität als obligatorisches oder lediglich fakultatives (wenn auch häufiges) Charakteristikum von Sprichwörtern anzusehen ist.”

92 Figurative proverbs are based on pictures and therefore are seen as true (metaphorical) concepts. Example: No rose without a thorn. Non-figurative proverbs are literal (non-metaphorical) proverbs which are generally understood word for word. Example: To err is human. Taylor (1932) differentiates between metaphorical proverb and proverbial apothem, Barley separates proverb proper from maxim and Permjakov distinguishes actual proverbs from popular aphorisms (Grzybek, 1998: 134).

93 Lüger (1999).

94 Duden 11: Redewendungen, 624. 
Projection / Model function: Both metaphor and proverb have a similar function in bridging new concepts with known ones: They are linguistically stereotyped models for a standardizing organization of new concepts (situational or other).

Form: Proverbs as well as metaphors have a concise form which is based on holism. ${ }^{95}$

Taking these similarities into account, we need to accept proverb concepts (PCs) in order to define proverbs (Lewandowska \& Antos, 2001). That is to say the comprehension of proverbs is predicated on certain cognitive concepts which can be compared to metaphorical concepts (MC). Not only do these concepts pre-structure our thoughts and actions to a great extent, but at the same time they put linguistically catchy words into our mouth.

We will now look at the role of PCs in two proverb examples whose lexical units are easily understood, but not their proverbial sense. The first example is from Kenya: With the brother's stick the brother is beaten. ${ }^{96}$

It is almost impossible to catch the meaning of this proverb, which is incredible because it contains a "pictorial message [...] that [does] not seem completely incomprehensible in the [...] translation at first sight” (Lüger, 1999: 20). Despite its verbal image we need the knowledge of the underlying proverb concept for a full comprehension. This concept can be based on cultural background knowledge among others. Here, the Kenyan proverb means as much as You will be blamed for the actions of your relatives; for them you expose yourself to the rage of others or have to accept other disadvantages.

The second example is from China and translates into English as follows:

He is the grass on the wall. ${ }^{97}$

Like with metaphors or certain idioms, for instance, most people would not be able to extrapolate the meaning of this proverb merely from its wording. That is why we use it as a proverb here. This Chinese proverb has the following meaning: It does not matter in which direction the wind blows, the grass always bends in the same direction ${ }^{98}$. The underlying concept can be described as: Wherever a peer-group pressure emerges, the correct match will help to avoid it.

95 Liebert (1992: 14). For more details - see 6.1 and 6.3.

96 Schlee (1991: 166), cited in Lüger (1999: 20).

97 Günthner (1994: 266), cited in Lüger (1999: 20).

98 The two proverb meanings are cited in Lüger (1999: 20). Interestingly, Lüger additionally presents the German equivalent for further comprehension: sein Mäntelchen nach dem Wind hängen [to turn one's coat] or sein Fähnchen nach dem Wind drehen [to jump on bandwagons]. 


\subsection{Structural Elements of Proverb Concepts}

\subsubsection{Linguistically Concise Form}

We recognize proverbs as proverbs due to their linguistically concise form (gestalt). This term derives from the field of gestalt psychology. Lakoff "introduces [it] as a profound and universal explanation model into the linguistic discussion" (Liebert, 1992: 24). A form in the sense of the gestalt psychology is characterized by two features, known as structural qualities: transposability and supra-summativity. ${ }^{99}$

We will now expand on the first feature transposability. Transposability means independence of the material. If we sing or whistle a melody, change the tune or play it with this or that instrument up or down one octave, we will always recognize the same melody, even if the stimulation pattern is electro-acoustically different (Liebert, 1992: 16). ${ }^{100}$

In a transferred sense, it means: recognizing a melody is similar to recognizing a linguistic stimulation pattern as a proverb (or rather proverb-alike formula) if you are able to transpose the information of the proverb form onto a specific sense. In other words, proverbs are perceived as proverbs independently of their material, e.g. their individual language or particular variations. The same holds true for the proverb concept which has to remain discernible despite its specific phrasing.

\subsubsection{Syntactic-semantic Structure}

In the field of paremiology, it is often pointed out that proverbs have particular syntactic and semantic structural features. Typical syntactic features are summarized under the term construction forms:

Construction forms of a proverb distinguish between two-word [phrases] (ger. 'Eigenlob stinkt' (eng. equivalent He that praises himself spatters himself), lat. 'varietas delectat' (eng. Variety delights.), ger. 'Bargeld lacht' (eng. equivalent Cash is king.)) and three-word phrases (ger. 'Rost frisst Eisen.' (eng. Rust penetrates steel.), ger. 'Arbeit macht frei' (eng. Work brings freedom.). Imperative forms often meet the moral demand of the proverb (e.g. ger. 'Hilf dir selbst, so hilft dir Gott' (eng. Heaven helps those who help themselves), ger. 'Verliebe dich oft, verlobe dich selten, heirate nie!' (eng. Often fall in love, seldom get engaged, never marry!)) as do formulas like should,

99 The term supra-summativity will be further investigated in connection with the issue of holism. See the section after next.

100 Ger. original: “Transponierbarkeit bedeutet Unabhängigkeit vom Material. Ob wir eine Melodie singen oder pfeifen, sie in verschiedenen Tonarten, eine Oktave höher oder tiefer mit diesem oder jenem Instrument spielen - stets erkennen wir die gleiche Melodie, obwohl elektroakustisch völlig verschiedene Reizmuster vorliegen.“ 
must and must not (e.g. ger. 'Man soll den Tag nicht vor dem Abend loben' (eng. equivalent Do not count your chickens before they are hatched.), ger. 'Alte soll man ehren, Junge soll man lehren' (eng. Honour the old and teach the young.) (Röhrich \& Mieder, 1977: 60). ${ }^{101}$

These construction forms are also called structural models ${ }^{102}$. Here are two German examples:

Lieber den Spatz in der Hand, als die Taube auf dem Dach. [ee: A bird in the hand is worth two in the bush.]

Lieber ein lebender Feigling als ein toter Held. [ee: Better a living dog than a dead lion.]

The underlying structural model can be outlined in the following way:

LIEBER (BESSER) A ALS B ${ }^{103}$

This model is also productive in other languages:

Spanish: Más vale soltero andar que mal casar. [ee: Rather remain single than marry badly.]

Dutch: Liever brood in de zak, dan een pluim op de hoed. [ww: A piece of bread in the bag is better than a feather on your hat]

English: Rather get an upset stomach than let anything go back to the innkeeper.

Italian: Meglio l'uovo oggi che la gallina domani. [ee: The egg today is better than the chicken tomorrow.]

For the Spanish, Dutch, English and Italian examples the underlying structural models are listed below:

Spanish: MÁs VALE A QUE B

Dutch: LIEVER A DAN B

English: RATHER (BETTER) A THAN B

Italian: MEGLIO A CHE B

In German, other proverbial structure models and variations include the following: A IST A (tautology): Dienst ist Dienst, Schnaps ist Schnapseng. [ww: Duty is duty, liquor is liquor.]

101 Ger. original: „Bei den Bauformen des Sprichworts kann man zunächst Zweiwort-Figuren (,Eigenlob stinkt‘, ,Varietas delectat‘, ,Bargeld lacht‘) und Dreiwort-Figuren unterscheiden (,Rost frisst Eisen', ,Arbeit macht frei'). Dem moralischen Anspruch des Sprichworts entsprechen häufig imperativische Formen (,Hilf dir selbst, so hilft dir Gott‘, ,Verliebe dich oft, verlobe dich selten, heirate nie!‘) und insbesondere die Formeln man soll, man muß, man darf (nicht) (...) (z.B. ,Man soll den Tag nicht vor dem Abend loben', ,Alte soll man ehren, Junge soll man lehren').“

102 Röhrich \& Mieder (1977: 60) also call them thinking-stencils.

103 All German examples here and hereafter are taken from Röhrich \& Mieder (1977). 
A BLEIBT A: Doof bleibt doof, da helfen keine Pillen. [ww: Stupid remains stupid, there is no cure.]

A IST B (identity phrase): Zeit ist Geld [ee: Time is money]

WIE MAN A, So AUCH B: Wie man sich bettet, so liegt man. [ee: As you make your bed so you must lie in it]

A SCHÜTZT NICHT VoR B: Alter schützt vor Torheit nicht. [ee: There is no fool like an old fool]

Again most of these models can be found in a variety of other languages. Here are the corresponding examples:

A IS A: English: A friend in need is a friend indeed.

A Is B: English: Time is money.

A ER B: Icelandic: Hefndin er sæt. [ee: Vengeance is sweet]

TAL A, TAL B: Portuguese: Tal pai, tal filho. [ee: Like father, like son]

QuALE A, TALE B: Italian: Quale uccello, tale nido. [ww: Like the bird, so is his nest]

A A NÃo EviTA B: Portuguese: A idade não evita estupidez. [ee: There is no fool like an old fool]

Syntactic-semantically, these structural models are similar to the cognitive concepts which have been hypothesized by Lakoff and Johnson for their conceptual metaphors. The three different types of conceptual metaphors are listed below:

Structural metaphor: ARGUMENT IS WAR

Orientational metaphor: HAPPY IS UP; SAD IS DOWN

Ontological metaphor: INFLATION IS AN ENTITY ${ }^{104}$

Last but not least, from the cognitive perspective transposability is a key element to create PCs.

\subsubsection{Holism}

What is holism? Most definitions emphasize two aspects: 1. We follow the general principle: The whole is more than the sum of its parts! 2. With only a few (culturally specific) meaningful characteristics it is possible to create a complete image or a certain meaning entirely, e.g. smileys. The feature of transposability (see 6.1) is also based on this kind of holism. In the following, we add a feature which is known as supra-summativity in the sense of the gestalt psychology: "The whole melody can sound mournful or merry, but not its individual sounds, i.e. the characteristics of the

104 All examples are taken from Lakoff \& Johnson's Metaphors We Live By (1992). 
whole form (here: the melody) are not the characteristics of its parts (here: the individual sounds) and vice versa” (Liebert, 1992: 17). ${ }^{105}$

Supra-summativity as a form of holism is known as idiomaticity within the field of phraseology. In paremiology, it is discussed in connection with imagery. In so far, it is correct as metaphors can act as images when seen as a whole. But: Not every single proverb must be based on imagery, but on holism however! Johnson discusses supra-summativity as image schemas: "Image schemas are neither specific pictures nor abstract propositions, but rather holistic forms with simple internal structures and can be 'applied' to a good deal of perceptions and events" (Drewer, 2003: 13). ${ }^{106}$

Holism that rests on supra-summativity: What is the consequence for explaining proverb concepts? Let us look at an example by Permjakov who attributes the variety of proverbs worldwide to relatively few deep-structured image schemas (Permjakov 2000: 70). He summarizes the following proverbs from different cultures into group 20:

$20 \mathrm{KA}$ The sun warms the flower and the dunghill likewise (Tamil)

$20 \mathrm{~KB}$ You would not tell the same to the blacksmith as to your wife (Rwanda)

20 LA The sun shines the same way for everybody (Tadjik)

$20 \mathrm{LB}$ Even the sun does not shine the same way for everybody (Karelian)

These four proverbs are summarized under one construction type only. In his reasoned notation Permjakov (2000: 70) describes it the following way: "If a certain thing has a relation to other things which are connected in a certain way, the relation to one of them concurs with the relation to the other one of them or not. ${ }^{107}$

Immediately, it becomes clear that this abstract kind of construction type is hardly memorable for speakers, not least because Permjakov's expressions cannot create mental images. Proverb concepts, however, are constructed as models for new situations and offer the agent not only isolated, but also supra-summatively connected information. Plus: Cognitivist explanations of this kind have the advantage that these four proverbs can be assigned to two opposing PCs:

105 Ger. original: "So kann zwar eine Melodie traurig oder fröhlich klingen, nicht aber die einzelnen Töne, d.h. Eigenschaften der ganzen Gestalt (hier: der Melodie) sind nicht Eigenschaften der Teile (hier der Einzeltöne) und umgekehrt.“

106 Ger. original: "Bildschemata sind weder konkrete Bilder noch abstrakte Propositionen, sondern vielmehr holistische Gestalten mit einfachen internen Strukturen, die sich auf unendlich viele Wahrnehmungen und Ereignisse ,anwenden“ lassen“

107 Ger. original: "Wenn eine bestimmte Sache eine Beziehung zu anderen Sachen aufweist, die auf bestimmte Art und Weise miteinander in Verbindung stehen, so fällt ihre Beziehung zu der einen von diesen mit ihrer Beziehung zu der anderen von ihnen zusammen oder nicht.“ 
PC 1: EVERYBODY PROFITS FROM A GOOD THING

PC 2: SOMETHING GOOD DOES NOT STRIKE EVERYBODY

\subsubsection{Structural Simplicity}

Proverb concepts need to be simple in structure. By this means, they can be used as models for new situations of use. Therefore, structural simplicity is the basis for their downright proverbial ability to be used in completely different (and also new) situations. Structural simplicity comprises the following aspects:

Basic Level Concepts: Humans create their cognitive concepts on an intermediate abstraction level: Hinting at results from Cognitive Sciences, Lakoff ${ }^{108}$ and Johnson point out that there are basic level concepts "which do not automatically meet a logical categorization:As an example, neither do we use the superior concept ANIMAL nor the subordinate concept DACHSHUND, but the holistic basic level concept DoG." ${ }^{109}$ These basic level concepts on an intermediate abstraction level are well-suited candidates for the creation of proverb concepts.

Perspectivation: Lakoff and Johnson point out that "the metaphorical structuring of concepts is [...] partial"110. That is to say in creating a meaning metaphorical concepts, on the one hand, highlight something, on the other hand, hide other aspects of the same reality ${ }^{111}$. This results from the fact that we can only perceive the world from one specific perspective.

Idealized Cognitive Models (ICM): Categorizing a situation, Proverb concepts idealize inevitably. In other words, they not only have to block out many aspects, but they add up, as well: "We do not find circles, rectangles or triangles in nature, not in the mathematical sense. Still an idealized cognitive model of a circle makes sense to orientate oneself within reality or for the construction of objects [...]” (Liebert, 1992: 52).

108 "Lakoff's key assumption for the basic level quotes: It holds true for both people and objects: Within a hierarchic classification a certain level, the socalled level of genus, excels in universally being the psychological basis of cognition for each speech community” (Liebert, 1992: 60).

109 Drewer (2003: 18). Ib.: “'Basic level concepts', or fundamental experiences of an intermediate abstraction level, are well-suited "candidates" for a metaphorical projection. Already toddlers acquire these concepts which are easy to remember and enable a holistic perception of form.”

110 You find more in Lakoff \& Johnson (1992). They give the following example: Theories are buildings. This metaphor is plausible if you, for instance, consider the foundation of a theory. The concept becomes implausible if you say, for example: His theory is covered with gargoyles. Hence, metaphorical concepts have used and unused parts.

111 Further information on this in Lakoff \& Johnson (1992). Ib.: "The very systematicity that allows us to comprehend one aspect of a concept in terms of another [...] will necessarily hide other aspects of the concept. In allowing us to focus on one aspect of a concept [...] a metaphorical concept can keep us from focusing on other aspects of the concept that are inconsistent with that metaphor". 
Due to their nature, idealized PCs reduce and simplify reality to a certain degree, but they rather construct it within their function as thinking models (Liebert, 1992: 52). ${ }^{112}$

\subsubsection{Cultural Frame}

To fully understand proverb concepts it is necessary to consider the cultural frame of proverbs (at a certain point of time). As an example, a new proverb emerged in the Germany of the 1970s: Eine Frau ohne Mann ist wie ein Fisch ohne Fahrrad. [A woman without a man is like a fish without a bicycle.]

Non-German-speakers might ask themselves: Is it maybe about the relationship between fish, women, bicycles and men? Only if you consider the cultural and timetypical knowledge of the emancipation movement of women, it is clear that the key word thematizes the relationship of emancipated women and men; and the meaning of the proverb becomes obvious. The appeal in this proverb lies in the exemplification of this relationship with the slightly absurd use of a non-existing relationship between fish and bicycles; but only if you know the correct cultural frame or have become accessible to it. ${ }^{113}$ When the knowledge of a cultural frame fades away, proverbs remain identifiable as proverbs, but they lose their significance as a proverb.

Let us explain a drastic example of an old proverb ${ }^{114}$ :

Frauen und Teppiche wollen geklopft werden. [ww: Women and carpets want to be beaten]

In this fortunately no longer used proverb women are ranged with fitments quite naturally, not even taking the obvious gender discrimination into account. What is highlighted gaudily with the word want in the then men-ruled society, is the assumption that it belongs to the functionality of these objects to be beaten. Behind this, we

112 "In order to throw certain aspects into sharp relief (operating on the principle of highlighting) it is possible to project the ICM ('Idealized Cognitive Models') of different experiences on a target. Hereby, the abstract field of politics [...] can be structured metaphorically by the ICM of games, sports, theatre, trade and war [...] which each foreground other aspects” (Baldauf, 1997: 80).

113 This proverb has already been recorded lexicographically and therefore acknowledged as a new proverb obviously; (Duden 12: Zitate und Aussprüche, 178). Meanwhile the German proverb seems to have been taken up by the Polish language in the word-for-word translation: Kobieta bez mężczyzny jest jak ryba bez roweru; Pani Vol.. 2(2003, 30), in the text titled Natychmiast kogoś mieć by Agnieszka Graff, who is the author of the very controversial book Świat bez Kobiet [The world without women]. If this proverb is understood by the Polish indeed, is doubtful according to a small private survey among Polish women or colleagues. In the newest phraseology and proverb dictionaries of my knowledge the new proverb is not listed.

114 Lüger (1999: 59). 
find the perspectivation of an assumed implicitness: In order that carpets and women remain in tidy or good condition you have to treat them accordingly. The seemingly stringent logic of the proverb lies behind this analogization which must have been adopted in the PC at that time. In this example, the as good and rightfully depicted male violence is completely hidden.

\subsubsection{Ability to Project}

Like metaphors, proverbs function as mappings. Owing to this feature, both similar proverbs in one language and proverbs from different cultures can be grouped into a joint PC. Let us compare the following proverbs:

English: Rome wasn't built in a day115

Polish: Nie od razu Kraków zbudowano [ww: Cracow was not built instantly]

German: Lübeck ist in einem Tage gestiftet, aber nicht in einem Tage gebaut ${ }^{116}$ [ww: Lübeck is donated in one day, but not built in one]

German: Gut Ding will Weile haben [ww: Good things require time.; ee: Rome wasn’t built in a day.]

Apparently, these proverbs express something similar or the same. Therefore, we assume that all four proverbs are based on the same concept: SUCCESS REQUIRES TIME.

PC

SUCCESS REQUIRES TIME

Proverbs

Rome wasn't built in a day.

Nie od razu Kraków zbudowano.

Lübeck ist in einem Tage gestiftet, aber nicht in einem Tage gebaut.

Gut Ding will Weile haben.

If we have a closer look, we notice distinct shades of meaning. Let us start with the first two examples. Nobody would claim seriously that either Rome or Cracow have been built instantly. The implicature which results from the contravention of maxims aims at the justification for a long actionIn the last example the focus is on something different: As a confirming statement it expresses that many sophisticated actions are planned quickly indeed, but cannot be realized as quickly. The quality of the long

115 Röhrich, Vol. 4 (1994: 1252). You use this proverb if "you (want to) explain yourself why something takes longer than expected [...]”.

116 Simrock (1988: 338). 
lasting action is highlighted here (a good job will take a while). These differences can be registered as follows:

The realization of a complex action takes a considerable time

SOPHISTICATED ACTIONS ARE QUICKLY DECIDED ABOUT, BUT TAKE TIME UNTIL THEIR COMPLETION

SUCCESS REQUIRES TIME

What can we conclude for the mapping? In formulating Success needs time, the PC has the strongest ability to project. Against this backdrop, we understand why Lakoff and Johnson chose easy structures for their metaphorical concepts. ${ }^{117}$ Proverb concepts create a joint cognitive basis for the intercultural comprehension of proverbs in different languages because of their ability to project. As a rule: the easier a PC is in structure, the stronger is its projection-ability for the (intercultural) comprehension of proverbs.

\subsubsection{Ability to Implicate}

Proverb concepts are complex cognitive concepts. Therefore, we have to postulate an implicature-ability ${ }^{118}$ for them. It is necessary in order to explain why we are able to instantly understand so-called anti-proverbs" (Mieder, 1982). Let us look at the following example ${ }^{119}$ : In an advertisement the German proverb Andere Länder, andere Sitten $^{120}$ [ww: Other countries, other customs] has been converted into Andere Länder, gleiche Auskunft [ww: Other countries, the same information]. Why can a client understand that despite the change? The key to this new understanding of the anti-proverb (AP) is based on our ability to implicate. We can reconstruct this ability to some extent in the following way:

117 In the appendix of her dissertation Baldauf (1997: 305-338) lists a plethora of metaphorical concepts with a thoroughly easy structure (it goes as far as dissolving syntax), e.g. Emotionality is warmth, Costs are heavy, Much is height/Size, Intimacy is physical closeness.

118 See the explanation by Auer (1999: 94): "Grice uses this coinage (implicature - A.L.) as a kind of ending which is necessary to get from what was said [...] onto what was meant [...]."

119 The example dates from an advertisement in the Spiegel magazine Vol. 39 (1999: 119). You find the full script of the analysed advertisement in Lewandowska \& Antos (2001).

120 [ee: When in Rome, do as the Romans do]. 


\section{AP}

Andere Länder, gleiche Auskunft

proverb original

(lexicographed form)

Andere Länder, andere Sitten proverb variation

(anti-proverb)

Andere Länder, gleiche Auskunft
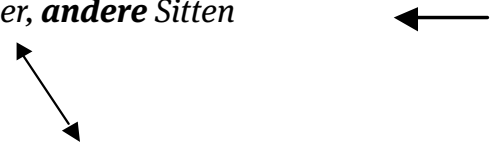

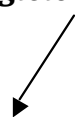

PC

PLAN ON MEETING OTHER CUSTOMS IN FOREIGN TERRITORIES

In the process of creating a meaning of proverb variations we make reference to:

- common linguistic features with the proverb original

- the concept which might underlie the proverb original

- formulations which differ from the proverb original

- the meaning of the proverb original.

We have to draw conclusions which are very much alike Grice's implicatures. If you try to phrase these implicatures for the example above the result could be as follows:

An expression is obviously used as slogan in an advertisement: Andere Länder, gleiche Auskunft.

- The slogan displays a similarity in its first part (Andere Länder"), but differs considerably from the original in its second part (gleiche Auskunft).

- This deviation shares the same dyadic structure like the original proverb and does not seem to be a misquoted proverb, but a planned variation!

- As would seem natural, the starting point for the new concept of the proverb variation is the proverb concept of the original PLAN ON MEETING OTHER CUSTOMS IN FOREIGN TERRITORIES.

- The PC contradicts the wording of the slogan Andere Länder, gleiche Auskunft notably, even if only partially.

- As a consequence, there is an opposition between the meaning of the original PC and the new meaning of the anti-proverb. Both are in concessive proportion to each other: Although foreign countries are 'otherwise' indeed, in this case you do not need to plan on different customs.

Thereby, the new concept of the proverb variation arises: DESPITE THE OTHERNESS OF OTHER COUNTRIES, EVERYTHING WILL REMAIN UNAFFECTED. This kind of interlinked 
implicature is not only a model to extrapolate from the proverb surface (what was said) to what was meant, but it also shows that PCs do not necessarily have to be cognitively firmly established. Instead they can be deduced or rather have to be deduced. In this respect, the ability to implicate illustrates the dynamic aspect of PCs.

\subsection{The Relation of MCs to PCs}

Comparing Lakoff and Johnson's metaphorical concepts (MCs) with the now specified proverb concepts (PCs), the question arises: what is the relation between these two types of concepts? It seems acceptable to say that metaphors and (metaphorical) proverbs are functionally equivalent because both are based on the same type of (complex) concepts. That is why the reception of Lakoff and Johnson's Conceptual Metaphor Theory plays an important role here.

Critically judged, it could be that not all proverbs are based on metaphors. While “'figurative' (actual) proverbs are visually motivated, the motivation of 'literal' proverbs is direct". ${ }^{121}$ Here language alone has to carry out what a metaphor does in figurative (metaphorical) proverbs. To be more precise: the concepts of literal (nonmetaphorical) proverbs are produced through statements of propositions. Let us look again at the above mentioned example. Stating that Rome, Lübeck and Cracow have not been built in one day does not mean that we refer to a (simple) picture like in, for instance: No rose without a thorn. The proverb about Rome/Lübeck/Cracow makes reference to the metaphor of building, but it is based on a wisdom which could be paraphrased in the following way: The one who builds a house of a city, needs a lot of time. Therefore, the statement that cities are not built in one day cannot be viewed visually (i.e. pre-linguistically coined). On the contrary, the cited proverb and a proposition form a frame together which refers to an individual and cultural life experience. This kind of propositionally coined proverb will indeed be able to illustrate a circumstance or situation. ${ }^{122}$

Here, the direction of the foundation is decisive: It is a difference if a metaphor (e.g. the rose-metaphor) is the foundation of the proverb concept or if the proverb

121 According to Grzybek (1998: 146) with reference to Permjakov's theory of proverb motivation. 122 You find a similar distinction in Grzybek (1998: 148): "Against the backdrop of what was said, [German] proverbs like Der Apfel fällt nicht weit vom Stamm [ee: The apple doesn't fall far from the tree (stem)]; Auf Regen folgt Sonnenschein [ee: Every cloud has a silver lining]; Viele Köche verderben den Brei [ee: Too many cooks spoil the broth], and others can be assigned to figurative proverbs easily, while not only 'nonpictorial' proverbs like Wer wagt, gewinnt [ee: Who dares, wins]; Aller Anfang ist schwer [Every beginning is difficult];or Ausnahmen bestätigen die Regel [ee: Exceptions prove the rule] belong to the group of literal proverbs, but also others like Reden ist Silber, Schweigen ist Gold [ee: Speech is silver, silence is golden] or Lügen haben kurze Beine [ee: A lie has no feet] despite their incorporated images." 
illustrates a circumstance itself (e.g. Build a city as the image for a time-consuming action). That is to say, literal proverbs are able to visualize circumstances by all means. You could also say these proverbs are able to paint a picture; but only with language and not with the help of a pre-linguistic imagery.

Our last example will show that the sophisticated concept of a non-metaphorical proverb can be based on language instead of an image: Gut Ding will Weile haben [ww: Good things require time.] In contrast to the proverbs about city planning, it is obvious that in this last example nothing is painted any more, it does not even illustrate an experience. Therefore, propositionally coined proverbs can express something, independently of imagery.

Hence, we have to record against Lakoff and Johnson: The world can be understood without any metaphors, solely through our language! It does not, however, invalidate the significance of Lakoff and Johnson's use of metaphors. Many abstract things can indeed be understood through metaphors. Taking this knowledge into account, we receive a differentiated view of the constitution of complex concepts. For second-class non-metaphorical (or non-figurative) proverbs it means that metaphorical concepts and proverb concepts of literal proverbs differ according to their cognitive foundation!

Interim conclusion: On the one hand, we have PCs which are functionally equivalent to MCs, and on the other hand, we have to postulate PCs which have circumstances and language as foundations. We find this not surprising. Theoretically speaking, the strict separation above proves unsatisfying. This holds true not least because traditional paremiology already points at the gradual nature of the transition from abstract (literal) to metaphorical proverbs. ${ }^{123}$ Lüger (1992: 72ff.) seizes on this differentiation and extends it by pointing out various levels of imagery. He emphasizes: "Imagery is no feature which a priori belongs to the respective idioms in any case.” The combination of verbal and non-verbal has to be considered as well as valuations or contexts:

Imagery in sentential idioms has something [...] to do with the effectivity of texts, the intended reaction of the audience or reader. It makes utterances flashier, or even more attractive and helps to make them graspable and remembered more easily, conditions permitting. (Lüger, 1999: 71). ${ }^{124}$

123 Grzybek (1998: 135) explains that Seiler (1922) already highlighted the „impossibility to separate strictly". "Further the difference between proverbs where the imagery takes possession of the whole proverb on the one hand, and others where the imagery only covers a part of the saying, on the other hand."

124 Ger. original: "Bildhaftigkeit in Satzphraseologismen hat also (...) auch etwas mit der Wirksamkeit von Texten, mit den angestrebten Reaktionen beim Hörer oder Leser zu tun: Sie macht sprachliche Äußerungen auffälliger, vielleicht auch attraktiver, und sorgt unter Umständen dafür, daß diese leichter erfaßt und besser behalten werden.“ 
Nevertheless, imagery supports the attractive grasp of complex circumstances, but it is no precondition for the linguistically founded comprehension (like Lakoff and Johnson suggest with their Conceptual Metaphor Theory).

This has theoretical consequences. Let us recall: In their approach, Lakoff and Johnson assume that the cognitive is priorized over language. The creation of meaning goes one-way from the pre-linguistic experience, from images and corporeality towards their manifestation in language. Liebert adds that basic ideas and all consequently deriving ideas are determinated by pre-conceptual structures and that the direction from language to experienceable structures is irreversible (1992: 79).

Hence, according to Lakoff and Johnson there is no "determining direction from language past cognition to perception" (Liebert, 1992: 77). As we have seen with nonmetaphorical proverbs they rest upon the power of language instead of metaphors. Here, the determining direction is reversed. Lakoff and Johnson's exclusiveness of the determining direction is therefore critized by Liebert (1992: 79) with good reason: "We have to assume a correlation in which terms (as cognitive basic models) are understood as linguistically fixed in their pre-linguistic experience. These terms form this experience due to their linguistic fixation."125

Now we assume a two-way determination of cognition and language in rather simple concepts, especially in proverbs which practically cannot be understood without their cultural background. In the following German examples, the required interplay between cognition, language and culture are demonstrated:

Wer A sagt, muss auch B sagen. [ee: In for a penny, in for a pound] Mitgefangen, mitgehangen [ee: Cling together, swing together]

In cognitive linguistics, the comprehension of both proverbs can be ascribed to a pre-linguistic causality experience and express a cause-effect relationship. They also illustrate how this relationship is expressed and differentiated in language. In the first example, a (probably unpleasant) consequence of an action is pointed out referring to the order of the alphabet as if painting them. This illustration only works for people who are familiar with the European alphabet. If you have not been socialised in our culture, it will prove difficult to understand the second example as well. Here, in connection with history (The prototypic punishment for felony is going to the gallows!) a cause The one who follows... is linked to a bitter consequence ...will go to the gallows as well.

125 Ger. original: "Es muß eine Wechselbeziehung angenommen werden, in der Begriffe (als Kognitive Rundmodelle) zwar als sprachlich instantiierte Fixierung vorbegrifflicher Erfahrung verstanden werden, diese Begriffe aber die Erfahrung durch eben ihre sprachlich instantiierte Fixierung auf bestimmte Art formen." 
The bottom line is that: Both proverbs make reference to certain pre-linguistic experiences, which is to say to the link between causes and effects. But how these experiences are expressed in the proverbs depends on the cultural or historic conditions and their resulting knowledge frames. We deal with a very typical mix ratio of pre-linguistic and cultural-linguistic conception. What is the consequence for the relationship between metaphorical concepts and proverb concepts? Without negating the significance of Lakoff and Johnson's Conceptual Metaphor Theory, it has to be complemented in the following way:

Not only can proverb concepts be created through imagery, but through language as well! In contrast to Lakoff and Johnson, when we create proverb concepts the determining direction has to be two-way: On the one hand, metaphors are fundamental for our comprehension of proverbs. On the other hand, we create PCs on the basis of the (propositionally coined) language. Often, these two directions will correlate as well. If we pursue this path, the cognitivist approach will have to be embedded in an overall theory which allows the creation of concepts through "cognition" and "language" 126.

\section{References}

Aristoteles v384 - v322 (1993). Rhetorik. München: Fink.

Auer, P. (1999). Sprachliche Interaktion. Eine Einführung anhand von 22 Klassikern. Tübingen: Niemeyer.

Baldauf, C. (1997). Metapher und Kognition. Grundlagen einer neuen Theorie der Alltagsmetapher. Frankfurt am Main: Peter Lang.

Drewer, P. (2003). Die kognitive Metapher als Werkzeug des Denkens. Zur Rolle der Analogie bei der Gewinnung und Vermittlung wissenschaftlicher Erkenntnisse. Tübingen: Gunter Narr.

Duden (2002a). Redewendungen. Wörterbuch der deutschen Idiomatik (Vol. 11). Mannheim: Dudenverlag.

Duden (2002b). Zitate und Aussprüche (Vol. 12). Mannheim: Dudenverlag.

Feilke, H. (1994). Common sense - Kompetenz. Überlegungen zu einer Theorie des "sympathischen" und „natürlichen “ Meinens und Verstehens. Frankfurt am Main: Suhrkamp.

Feilke, H. (1996). Sprache als soziale Gestalt, Ausdruck, Prägung und die Ordnung der sprachlichen Typik. Frankfurt am Main: Suhrkamp.

Grzybek, P. (1984). Überlegungen zur semiotischen Sprichwortforschung. In P. Grzybek (Ed.), Semiotische Studien zum Sprichwort. Simple Forms Reconsidered I (215-249). Tübingen: Gunter Narr.

Grzybek, Peter (1998). Prolegomena zur Bildhaftigkeit von Sprichwörtern. In A. Hartmann \& C. Veldhues (Eds.), Im Zeichen-Raum: Festschrift für Karl Eimermacher (133-152). Dortmund: Projekt Verlag.

Lakoff, G. \& Johnson, M. (1992). Metaphors We Live By. Edition 9. Chicago: Univ. of Chicago Press.

126 Further reading: Feilke’s $(1994,1996)$ socio-cognitive approach. 
Lewandowska, A. \& Antos, G. (2001). Sprichwörter, metaphorische Konzepte und Alltagsrhetorik: Versuch einer kognitivistischen Begründung der Sprichwortforschung. Proverbium. Yearbook of international Proverb Scholarship 18, 167-183.

Liebert, W.-A. (1992). Metaphernbereiche der deutschen Alltagssprache. Kognitive Linguistik und die Perspektiven einer Kognitiven Lexikographie. Frankfurt am Main: Peter Lang.

Lüger, H.-H. (1992). Sprachliche Routinen und Rituale. Frankfurt am Main: Peter Lang.

Lüger, H.-H. (1999). Satzwertige Phraseologismen. Eine pragmalinguistische Untersuchung. Wien: Edition Praesens.

Mieder, W. (1982). Antisprichwörter (Vol. 1). Heidelberg: Quelle \& Meyer.

Permjakov, G. L. (2000). Die Grammatik der sprichwörtlichen Weisheit.: Mit einer Analyse allgemein bekannter deutscher Sprichwörter (Vol. 4). Baltmannsweiler: Schneider Verlag Hohengehren.

Röhrich, L. \& Mieder, W. (1977). Sprichwort. Stuttgart: Metzler.

Röhrich, L. (1994). Lexikon der sprichwörtlichen Redensarten (Band 1-5). Fourth Edition. Freiburg/ Basel/Wien: Herder.

Simrock, K. (Ed.) (1988). Die deutschen Sprichwörter gesammelt von Karl Simrock. Einleitung von Wolfgang Mieder. Stuttgart: Reclam. 